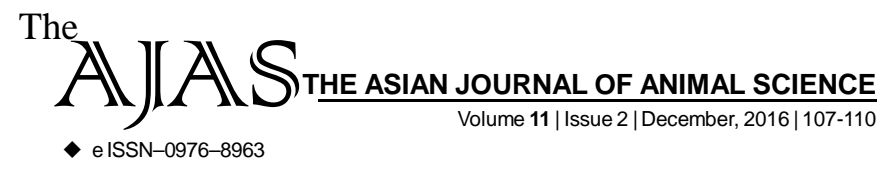

DOI : 10.15740/HAS/TAJAS/11.2/107-110
Visit us | www.researchjournal.co.in

RESEARCH ARTICLE........

\title{
Soil and water quality parameters of Brackish water shrimp farms of Ratnagiri, Maharashtra
}

MUDASSIR AZHAR, ASHISH S. MOHITE AND RAHUL SADAWARTE .

Author for Corresponding -

ASHISH S. MOHITE

Department of Fisheries

Engineering, College of Fisheries,

Shirgaon, RATNAGIRI (M.S.) INDIA

Email: ashishmohite@yahoo.com

See end of the article for

Coopted authors'
ABSTRACT...... Study was carried out on the soil and water quality parameters of operational Brackish Water Shrimp Farms of Ratnagiri district, Maharashtra. The soil quality parameters like Texture, $\mathrm{pH}$, Water holding capacity, Seepage rate and Bulk density whereas the water quality parameters are temperature, $\mathrm{pH}$, DO and Suspended Solid, Alkalinity, Hardness, Ammonia, carbon dioxide and Salinity. The soil $\mathrm{pH}$ ranged from 7.3 to 7.6. The bulk density was $1.164 \mathrm{~g} / \mathrm{cm}^{3}$ to $1.462 \mathrm{~g} / \mathrm{cm}^{3}$. Water temperature ranged from $28^{\circ} \mathrm{C}$ to $30^{\circ} \mathrm{C}$. The level of the Water $\mathrm{pH}$ ranged from 7.4 to 8.0, whereas the salinity of water ranged from 15 to $35 \mathrm{ppt}$.

KEY WORDS...... Shrimp farm, Soil quality, Water quality

HOW TO CITE THIS ARTICLE - Azhar, Mudassir, Mohite, Ashish S. and Sadawarte, Rahul (2016). Soil and water quality parameters of Brackish water shrimp farms of Ratnagiri, Maharashtra. Asian J. Animal Sci., 11(2): 107-110. DOI : 10.15740/HAS/TAJAS/11.2/107-110.

ARTICLE CHRONICLE - Received : 09.08.2016; Revised : 13.10.2016; Accepted : 28.10.2016 